\title{
Planktic foraminifers as recorders of seawater $\mathrm{Ba} / \mathrm{Ca}$
}

\author{
Bärbel Hönisch a,*, Katherine A. Allen ${ }^{a}$, Ann D. Russell ${ }^{\text {b }}$, Stephen M. Eggins ${ }^{\mathrm{c}}$, Jelle Bijma ${ }^{\mathrm{d}}$, Howard J. Spero ${ }^{\mathrm{b}}$, \\ David W. Lea ${ }^{\mathrm{e}}, \mathrm{Jimin}_{\mathrm{Yu}}{ }^{\mathrm{a}}$ \\ a Lamont-Doherty Earth Observatory of Columbia University, 61 Route 9W, Palisades, NY 10964, USA \\ ${ }^{\mathrm{b}}$ Department of Geology, University of California, Davis, CA 95616, USA \\ c Research School of Earth Sciences, The Australian National University Canberra 0200, Australia \\ d Alfred Wegener Institute for Polar and Marine Research, Bremerhaven, Germany \\ e Department of Geological Sciences and the Marine Science Institute, University of California, Santa Barbara, CA 93106, USA
}

\section{A R T I C L E I N F O}

\section{Article history:}

Received 6 November 2010

Received in revised form 24 January 2011

Accepted 25 January 2011

\section{Keywords:}

Planktic foraminifers

$\mathrm{D}_{\mathrm{Ba}}$

$\mathrm{pH}$

Salinity

Temperature

Culturing

\begin{abstract}
A B S T R A C T
Recent studies have used the $\mathrm{Ba} / \mathrm{Ca}$ ratio of planktic foraminifer shells as a proxy for river run-off at oceanic sites near estuaries. Such studies assume that the $\mathrm{Ba} / \mathrm{Ca}$ ratio in planktic foraminifer shells is primarily controlled by the $\mathrm{Ba} / \mathrm{Ca}$ concentration of seawater and that other parameters such as salinity, temperature and $\mathrm{pH}$ do not compromise the primary Ba concentration relationship. Here we provide new insights from culture experiments and review published studies to confirm that environmental parameters including $\mathrm{pH}$, temperature, salinity, and symbiont photosynthesis do not affect Ba substitution into planktic foraminiferal calcite. The partition coefficient for $\mathrm{Ba}$ in spinose planktic foraminifers is estimated as $\mathrm{D}_{\mathrm{Ba}}=0.15 \pm 0.05(95 \%$ confidence limits). The same factor also seems applicable to the non-spinose genus Neogloboquadrina but not to specimens of the non-spinose genus Globorotalia.
\end{abstract}

(c) 2011 Elsevier B.V. All rights reserved.

\section{Introduction}

Environmental information derived from the trace element composition of foraminifer shells is limited by the accuracy with which these calcite shells record ambient seawater chemistry and whether multiple environmental parameters or species-specific differences affect shell chemistry. Continued efforts to improve our understanding of geochemical proxy-relationships in planktic foraminifers have, for instance, revealed a significant $\mathrm{pH}$ effect on the $\mathrm{Sr} / \mathrm{Ca}$ and $\mathrm{Mg} / \mathrm{Ca}$ ratios (Kisakürek et al., 2008; Lea et al., 1999; Russell et al., 2004), a salinity effect on the $\mathrm{Mg} / \mathrm{Ca}$ ratio (Kisakürek et al., 2008), and pH and carbonate ion effects on the oxygen and carbon isotopic compositions under conditions of constant $\delta^{13} \mathrm{C}_{\text {DIC }}$ and $\delta^{18} \mathrm{O}$ of seawater (Bijma et al., 1999; Spero et al., 1997). Knowledge of such secondary effects may permit the correction of the primary proxy relationship if the secondary influence can be quantified (e.g. Zeebe, 2001).

Laboratory culture experiments indicate that barium $(\mathrm{Ba})$ is incorporated into the shells of the spinose, symbiont-bearing foraminifers Orbulina universa and Globigerinoides sacculifer in proportion to seawater concentration and that the incorporation is independent of secondary effects such as temperature, symbiont photosynthesis, and salinity (Lea and Spero, 1992, 1994). Hall and Chan (2004a) and

\footnotetext{
* Corresponding author. Tel.: +1 845365 8828; fax: +1 8453658155 . E-mail address: hoenisch@ldeo.columbia.edu (B. Hönisch).
}

Weldeab et al. (2007a, b) applied this information to planktic foraminifer shells to reconstruct past variations in the $\mathrm{Ba} / \mathrm{Ca}$ ratio of seawater as a proxy for deglacial meltwater discharge into the Arctic Ocean, and west African river run-off and monsoon intensity, respectively. Similarly, Sprovieri et al. (2008) measured the $\mathrm{Ba} / \mathrm{Ca}$ ratio in Neogene 0 . universa shells from the Mediterranean and interpreted their record in terms of river discharge and geographical constraints of the Mediterranean Basin. These interpretations of foraminiferal $\mathrm{Ba} / \mathrm{Ca}$ records are based on the observation that the seawater Ba concentration in estuaries and coastal waters is elevated relative to the open ocean and inversely correlated with salinity, as continental run-off supplies high concentrations of Ba to the ocean.

In the open ocean, dissolved barium ([Ba]) acts as a nutrient-like tracer similar to $\mathrm{Cd}^{2+}$ and $\delta^{13} \mathrm{C}$ because biological activity extracts these elements from surface waters and transfers them towards the seafloor via sinking particles (e.g. Bernstein et al., 1998). Dissolved Ba thereby covaries with silica and alkalinity (Chan et al., 1977), and although the mechanistic link between alkalinity and [Ba] is not fully understood (Lea, 1993), several studies have used the strong correlation between deep-ocean [Ba] and alkalinity to reconstruct past ocean alkalinity and paleocirculation patterns from $\mathrm{Ba} / \mathrm{Ca}$ ratios in shells of benthic foraminifers (Hall and Chan, 2004b; Lea, 1993; Lea and Boyle, 1989, 1990a, b).

The underlying assumption for the use of the $\mathrm{Ba} / \mathrm{Ca}$ ratio as an indicator for alkalinity in the deep ocean or continental run-off in coastal areas and estuaries is that the incorporation into foraminiferal shells depends only on the $\mathrm{Ba} / \mathrm{Ca}$ ratio in seawater. If Ba partitioning 
also responded to changes in ocean carbonate chemistry or salinity, the ability to estimate past salinity or seawater-Ba/Ca ratio variations would be hampered. One indication that Ba partitioning may be affected by parameters other than dissolved [Ba] comes from a laser ablation study of the symbiont-barren foraminifer Globorotalia inflata from sediment traps (Hathorne et al., 2009). Analysis of a single specimen shows a $\sim 6$-fold increase in the $\mathrm{Ba} / \mathrm{Ca}$ ratio from the outer surface towards the inside of the shell wall. Hathorne et al. (2009) observed a strong covariation between $\mathrm{Mg} / \mathrm{Ca}$ and $\mathrm{Ba} / \mathrm{Ca}$ ratios in the shell, but the high $\mathrm{Ba} / \mathrm{Ca}$ ratio of the inner portion of the shell is inconsistent with a supposed shallower growth habitat during early ontogeny of this species, which should reflect the lower Ba/Ca ratio of surface seawater. The cause for the $\mathrm{Ba} / \mathrm{Ca}$ pattern in this $\mathrm{G}$. inflata shell remains unresolved. It may reflect varying environmental parameters during shell secretion but it should be noted that the cleaning methods applied in this laser ablation study do not remove postmortem barite precipitates inside the shells. Lea and Boyle (1991) observed barite contamination in samples from sediments and sediment traps and suggested that barite must partly form in the water column. Lea and Boyle (1991) therefore introduced a cleaning step with alkaline diethylenetriamine-pentaacetic acid (DTPA) for barite removal from sedimentary and trap-collected foraminifer shells, which has since been applied to $\mathrm{Ba} / \mathrm{Ca}$ ratio measurements by solution chemistry but not for laser ablation studies. In contrast to findings of the laser ablation study, sequential dissolution experiments with DTPA-cleaned shells of Globigerinoides conglobatus and Globorotalia truncatulinoides, suggested homogeneous Ba/Ca distribution inside the shells (Lea and Boyle, 1991).

Previous studies have examined Ba incorporation into natural samples of Orbulina spp., Globigerinoides ruber, G. sacculifer, G. conglobatus, Neogloboquadrina dutertrei, and N. pachyderma sin. in relation to surface seawater Ba/Ca ratios (Hall and Chan, 2004a; Lea and Boyle, 1991), in cultured O. universa as a function of light intensity and seawater Ba concentration at constant temperature (Lea and Spero, 1992), and in cultured O. universa and G. sacculifer as a function of seawater $[\mathrm{Ba}]$, temperature and salinity in two different locations [O. universa from Santa Catalina Island in the NE Pacific at $22^{\circ} \mathrm{C}$, $\mathrm{S}=33.7$, and 0 . universa and $\mathrm{G}$. sacculifer from Lee Stocking Island, Bahamas at $29^{\circ} \mathrm{C}$ and $\mathrm{S}=36.7$; Lea and Spero, 1994]. Here we provide new constraints from culture experiments with 0 . universa and the symbiont barren Globigerina bulloides, grown under varying seawater $\mathrm{pH}$, temperature, salinity, and two different light levels. Our data confirm and expand the results of previous studies and demonstrate that environmental controls other than the $\mathrm{Ba} / \mathrm{Ca}$ ratio of seawater have no measurable effect on the $\mathrm{Ba} / \mathrm{Ca}$ ratio in spinose planktic foraminifers.

\section{Foraminifera collection and culturing}

Foraminifers for this study were cultured in two field seasons, JulyAugust 2000 and July-August 2008, using previously established methods (e.g. Lea and Spero, 1992; Russell et al., 2004). Juvenile (presphere) Orbulina universa and small G. bulloides were hand collected by SCUBA divers from surface waters of the San Pedro Basin, approximately $2 \mathrm{~km}$ NNE of the Wrigley Institute for Environmental Studies, Santa Catalina Island, California. Surface seawater for culturing was collected at the foraminifer collection site and filtered in the laboratory using acid-cleaned $0.4 \mu \mathrm{m}$ polycarbonate membrane filters and an acid-leached polysulfone filter holder (2000 field season), and $0.8 \mu \mathrm{m}$ nitrate cellulose filters on a borosilicate glass filter system (2008 field season).

After collection, each specimen was examined under an inverted light microscope for the purpose of species identification, shell dimension measurement, and inspection of general condition. Individual foraminifers were then transferred to $120 \mathrm{ml}$ glass jars containing the filtered experimental seawater. To avoid contamination of culture water during transfer and feeding of specimens, sample handling was done wearing powder free gloves and using acid-leached glass pipettes for feeding and transferring foraminifers.

Average summer seawater conditions at the collection site are $22^{\circ} \mathrm{C}$, $\mathrm{S}=33.5, \mathrm{pH}=8.04$ (total scale) and alkalinity $=2250 \mu \mathrm{mol} \mathrm{kg}{ }^{-1}$. It should be noted that the salinity measurements in 2000 and 2008 used different conductivity meters and yielded slightly different results $(S=33.7$ and 33.3, respectively). This difference is likely analytical rather than oceanographic, and it only applies to the $\mathrm{pH}$ experiments compared between 2000 and 2008. For comparison, WOCE oceanographic data from the coast of Southern California read $S=33.5$.

Foraminifer cultures were maintained in water baths at constant temperature (to $\pm 0.1{ }^{\circ} \mathrm{C}$ ) and light levels of 299-406 $\mu \mathrm{mol}$ photons $\mathrm{m}^{-2} \mathrm{~s}^{-1}$ (12-h high light/dark cycle). These light levels exceed the saturation light intensity for the symbiotic dinoflagellates associated with O. universa (Rink et al., 1998). Only one parameter was changed per experiment, with all others maintained constant at ambient conditions. Four sets of experiments were performed: 0 . universa was grown under $\mathrm{S}=29.9-35.4, \mathrm{~T}=18-26^{\circ} \mathrm{C}, \mathrm{pH}=7.6-8.64$ (total scale), and a low light experiment at $23 \mu \mathrm{mol}$ photons $\mathrm{m}^{-2} \mathrm{~s}^{-1}$ (12-h low light/ dark cycle). This light intensity falls below the light compensation point for the dinoflagellates' photosynthetic activity (Rink et al., 1998). G. bulloides was grown over a pH range of 7.61-8.52 (total scale). G. bulloides and 0 . universa were fed a 1-day old Artemia sp. nauplius (brine shrimp) every other or every third day, respectively.

During the 7- to 10-day culture period 0 . universa secretes and calcifies a spherical chamber, whereas G. bulloides forms between two and four new chambers. After the foraminifers underwent gametogenesis, empty shells were rinsed in ultrapure or deionized water and archived for later analysis. In addition, samples of the culture solutions were acidified, and analyzed to verify that seawater $\mathrm{Ba}$ and $\mathrm{Ca}$ concentrations remained constant over the course of the experiments.

Experimental $\mathrm{pH},\left[\mathrm{CO}_{3}^{2-}\right]$ and total alkalinity (AT) were simultaneously modified by the addition of ultrapure $\mathrm{HCl}$ to lower these quantities or the addition of ultrapure $\mathrm{NaOH}$ to increase them. Initial and final seawater $\mathrm{pH}$ were measured and alkalinity was determined by Gran-titration with a Metrohm 785 Titrino auto-titrator. In the year 2000 samples were also taken for dissolved inorganic carbon (DIC), collected at the beginning and end of each experiment, poisoned with a few drops of a saturated $\mathrm{HgCl}_{2}$ solution and measured coulometrically at the Alfred Wegener Institute. $\mathrm{pH}$, AT and DIC were all normalized to Dickson certified reference material, which was measured in parallel to the experimental seawaters.

Experimental seawater salinity was modified by either addition of deionized water or evaporation of filtered seawater under a heat lamp. All salinity experiments were conducted in 2008 and initial and final salinity were measured with a handheld Fisher Scientific 3-Star conductivity meter.

\section{Sample preparation for analysis}

Only gametogenic shells were used for analysis. All specimens were rinsed in distilled water to remove sea salts, dried and weighed. Chambers secreted under controlled conditions in the laboratory were separated from the juvenile portion of the shell grown in the ocean before collection. Shells grown in 2000 were prepared and analyzed at the University of California in Santa Barbara following the methods of Lea and Martin (1996), whereas shells grown in 2008 were prepared and analyzed in the Godwin Laboratory at Cambridge University following the methods of Yu et al. (2005).

O. universa shells grown in 2000 were cracked open with a disposable scalpel and the juvenile test (if present) was removed with a small brush. The fragments were then transferred to $0.5 \mathrm{ml}$ polypropylene centrifuge vials. Individual shells of 0 . universa were analyzed where possible, but for the smallest individuals, two or three shells were pooled to obtain at least $40 \mu \mathrm{g}$ of uncleaned calcite. For $G$. bulloides, chambers grown in the laboratory were identified by 
comparing the size of the specimen at collection with the size of the postgametogenic shell. The laboratory-grown chambers were amputated with a scalpel, pooled (25-35 chambers per sample) and loaded into $0.5-\mathrm{ml}$ polypropylene centrifuge vials. Samples were then subjected to a series of physical and chemical treatments including: oxidation in hot $\left(70{ }^{\circ} \mathrm{C}\right)$ buffered $\mathrm{H}_{2} \mathrm{O}_{2}-\mathrm{NaOH}(0.1 \mathrm{~N} \mathrm{NaOH}, 15 \% \mathrm{v} / \mathrm{v}$ $\mathrm{H}_{2} \mathrm{O}_{2}$ Seastar) solution to remove organic matter, 2-3 weak acid leaches $\left(0.001 \mathrm{~N} \mathrm{HNO}_{3}\right)$ and repeated rinses in ultrapure water. The amputation and cleaning procedures followed methods established by Mashiotta et al. (1997). DTPA cleaning is not necessary for cultured foraminifer shells, as they were dried and archived immediately upon gametogenesis. Sample analysis followed the multi-element inductively coupled plasma mass spectrometry (ICP-MS) method described by Lea and Martin (1996). After cleaning, 20-30 $\mu$ g size samples of purified foraminifer shells were dissolved in $0.5 \mathrm{ml}$ of a $0.1 \mathrm{~N} \mathrm{HNO}_{3}$ solution containing calibrated concentrations of ${ }^{135} \mathrm{Ba}$ and ${ }^{45} \mathrm{Sc}$. The solutions were aspirated into a Finnigan Element2 high-resolution magnetic sector ICP-MS. The ${ }^{135} \mathrm{Ba} /{ }^{138} \mathrm{Ba}$ and ${ }^{45} \mathrm{Sc} /{ }^{48} \mathrm{Ca}$ ratios were determined by pulse counting and analog acquisition modes, respectively. The concentrations of $\mathrm{Ba}$ and Ca were then determined by isotope dilution and internal standard calculation, respectively. $\mathrm{Na} /$ Ca was determined to be certain that the hydrogen peroxide-sodium hydroxide solution used in the sample preparation was completely rinsed out. Several analyses of a consistency standard with $\mathrm{Ba}$ and $\mathrm{Ca}$ concentrations similar to the foraminiferal samples had a standard deviation of $0.4 \%$ for $\mathrm{Ba}, 1 \%$ for $\mathrm{Ca}$, and $1.25 \%$ for the $\mathrm{Ba} / \mathrm{Ca}$ ratio. An average of 2-4 replicates was determined on 0 . universa. Due to the small sample yield in $\mathrm{G}$. bulloides only one $\mathrm{Ba} / \mathrm{Ca}$ analysis per experiment could be collected for this species.

Seventeen water samples were randomly selected for analysis of trace and minor element concentrations over the course of the experiment. These samples yield ambient seawater concentrations of $37.8 \pm 0.35 \mathrm{nmol} \mathrm{kg}^{-1}$ for [Ba] and $10.24 \pm 0.09 \mathrm{mmol} \mathrm{kg}^{-1}$ for [Ca]. The amount of $\mathrm{Ba}$ incorporated into the foraminiferal shell is negligible compared to the total [Ba] present in the experimental seawater (Lea and Spero, 1992). However, it is conceivable that problems could arise from barium contamination (e.g. during feeding) or adsorption onto the culture jar walls. Although one of the water samples showed [Ba] elevated by $11 \%$, the average change in seawater [Ba] was only $0.9 \%$, indicating that barium adsorption was negligible and contamination unlikely. Nevertheless, we cannot rule out the possibility that some foraminifers experienced Ba concentrations that may have differed from the average of $37.8 \mathrm{nmol} \mathrm{kg}^{-1}$.

Only 0. universa were grown in 2008. Samples consisting of $\sim 15$ shells were cracked and then cleaned in the same way as described above. Elemental analysis of this sample set was carried out in the Godwin Laboratory at Cambridge University following the methods of Yu et al. (2005). Calcium concentrations were first measured by ICPAES. Aliquots of the same solution were diluted to $100 \mathrm{ppm}$ [Ca] to minimize matrix effects during subsequent analysis by ICP-MS (PerkinElmer SCIEX Elan DRC II). Standards prepared with Milli- $\mathrm{Q}^{+}$ allowed a Ba/Ca detection range of 0.09-4.84 $\mu \mathrm{mol} / \mathrm{mol}$. Standard solutions were measured every $3-5$ samples, giving a $\sim 1.7 \%$ relative standard deviation (RSD). Only a few samples could be measured in duplicate with this method.

\section{Results}

\subsection{Carbonate chemistry, light level, and foraminifer species}

The experimental matrix and $\mathrm{Ba} / \mathrm{Ca}$ results are summarized in Table 1 and shown in Fig. 1a-d. Figs. 1a, b and 2 show Ba/Ca ratios of the same experiments relative to $\mathrm{pH},\left[\mathrm{CO}_{3}^{2-}\right]$ and total alkalinity, respectively. O. universa shells grown in 2000 and 2008 and measured in different labs give the same $\mathrm{Ba} / \mathrm{Ca}$ ratio within error: $0.67 \pm 0.04$ (Santa Barbara) and $0.69 \pm 0.03$ (Cambridge). Two 0 . universa analyses from this data set deviate by more than $2 \sigma$ from the experimental mean (Table 1). Both analyses were done on single large shells and although their interpretation would not change the conclusions from this study, we suspect these specimens may have suffered from elevated [Ba] in their respective culture jars, and have therefore excluded them from the figures and further evaluation.

G. bulloides has not been calibrated for $\mathrm{Ba} / \mathrm{Ca}$ before. The primary observation from our experiments is that $\mathrm{Ba} / \mathrm{Ca}$ ratios of the two

Table 1

Experimental seawater conditions and Ba/Ca data for new culture experiments performed in 2000 and 2008.

\begin{tabular}{|c|c|c|c|c|c|c|c|c|c|c|c|c|c|c|c|}
\hline Experiment & Light & Salinity & $\begin{array}{l}\text { Temperature } \\
\left({ }^{\circ} \mathrm{C}\right)\end{array}$ & $\begin{array}{l}\text { Alkalinity } \\
\left(\mu \mathrm{mol} \mathrm{kg}{ }^{-1}\right)\end{array}$ & $\begin{array}{l}\mathrm{pH} \\
\text { (total scale) }\end{array}$ & $\begin{array}{l}\text { Calc. DIC } \\
\left(\mu \mathrm{mol} \mathrm{kg}{ }^{-1}\right)\end{array}$ & $\begin{array}{l}\text { Calc. }\left[\mathrm{CO}_{3}^{2-}\right] \\
\left(\mu \mathrm{mol} \mathrm{kg}{ }^{-1}\right)\end{array}$ & $\begin{array}{l}\mathrm{Ba} / \mathrm{Ca}-1 \\
(\mu \mathrm{mol} / \mathrm{mol})\end{array}$ & $\mathrm{N}$ & $\begin{array}{l}\mathrm{Ba} / \mathrm{Ca}-2 \\
(\mu \mathrm{mol} / \mathrm{mol})\end{array}$ & $\mathrm{N}$ & $\begin{array}{l}\mathrm{Ba} / \mathrm{Ca}-3 \\
(\mu \mathrm{mol} / \mathrm{mol})\end{array}$ & $\mathrm{N}$ & $\begin{array}{l}\mathrm{Ba} / \mathrm{Ca}-4 \\
(\mu \mathrm{mol} / \mathrm{mol})\end{array}$ & $\mathrm{N}$ \\
\hline \multicolumn{16}{|l|}{ O. universa } \\
\hline BH1 & LL & 33.6 & 22 & $2253 \pm 10$ & $8.03 \pm 0.02$ & $2000^{*}$ & 182 & 0.61 & 1 & 0.70 & 3 & 0.57 & 2 & 0.59 & 2.0 \\
\hline $\mathrm{BH} 2$ & $\mathrm{HL}$ & 33.8 & 22 & $2268 \pm 5$ & $8.07 \pm 0.02$ & $1993^{*}$ & 196 & 0.63 & 1 & 0.71 & 2 & 0.67 & 2 & $(1.06)$ & 1.0 \\
\hline BH3 & $\mathrm{HL}$ & 33.7 & 22 & $2047 \pm 15$ & $7.61 \pm 0.03$ & $1965^{*}$ & 76 & 0.76 & 3 & 0.67 & 2 & & & & \\
\hline $\mathrm{BH} 4$ & $\mathrm{HL}$ & 33.7 & 22 & $2632 \pm 12$ & $8.52 \pm 0.02$ & $1979 *$ & 468 & 0.56 & 1 & 0.58 & 2 & 0.60 & 3 & 0.57 & 1.0 \\
\hline BH5 & $\mathrm{HL}$ & 33.7 & 22 & $2436 \pm 21$ & $8.30 \pm 0.01$ & $1997^{*}$ & 311 & 0.65 & 1 & 0.64 & 1 & 0.56 & 1 & $(1.01)$ & 1.0 \\
\hline BH6 & $\mathrm{HL}$ & 33.7 & 22 & $2122 \pm 6$ & $7.81 \pm 0.01$ & $1979^{*}$ & 111 & 0.60 & 1 & 0.60 & 2 & 0.57 & 2 & 0.70 & \\
\hline KA1 & $\mathrm{HL}$ & 33.2 & 18 & $2233 \pm 21$ & $8.08 \pm 0.03$ & 1990 & 175 & 0.69 & 15 & & & & & & \\
\hline KA2 & $\mathrm{HL}$ & 33.0 & 20 & $2229 \pm 5$ & $8.03 \pm 0.01$ & 2000 & 166 & 0.62 & 15 & & & & & & \\
\hline KA3 & $\mathrm{HL}$ & 33.3 & 22 & $2239 \pm 5$ & $8.01 \pm 0.02$ & 2001 & 173 & 0.71 & 15 & 0.67 & 15 & & & & \\
\hline KA4 & $\mathrm{HL}$ & 33.0 & 26 & $2237 \pm 10$ & $7.95 \pm 0.01$ & 2001 & 173 & 0.63 & 15 & & & & & & \\
\hline KA5 & $\mathrm{HL}$ & 33.3 & 22 & $2058 \pm 2$ & $7.60 \pm 0.02$ & 1991 & 70 & 0.67 & 15 & & & & & & \\
\hline KA6 & $\mathrm{HL}$ & 33.3 & 22 & $2425 \pm 4$ & $8.27 \pm 0.02$ & 2009 & 297 & 0.66 & 15 & & & & & & \\
\hline KA7 & $\mathrm{HL}$ & 33.3 & 22 & $2803 \pm 7$ & $8.64 \pm 0.03$ & 2013 & 577 & 0.62 & 15 & & & & & & \\
\hline KA8 & $\mathrm{HL}$ & 29.9 & 22 & $2040 \pm 9$ & $8.03 \pm 0.03$ & 1828 & 153 & 0.70 & 15 & 0.68 & 15 & & & & \\
\hline KA9 & $\mathrm{HL}$ & 31.5 & 22 & $2163 \pm 13$ & $7.99 \pm 0.05$ & 1949 & 157 & 0.68 & 15 & 0.71 & 15 & & & & \\
\hline KA10 & $\mathrm{HL}$ & 35.4 & 22 & $2385 \pm 0$ & $7.98 \pm 0.03$ & 2137 & 182 & 0.64 & 15 & & & & & & \\
\hline \multicolumn{16}{|l|}{ G. bulloides } \\
\hline BH1 & LL & 33.6 & 22 & $2253 \pm 10$ & $8.03 \pm 0.02$ & $2000^{*}$ & 182 & 0.65 & 35 & & & & & & \\
\hline $\mathrm{BH} 2$ & $\mathrm{HL}$ & 33.8 & 22 & $2268 \pm 5$ & $8.07 \pm 0.02$ & $1993^{*}$ & 196 & 0.55 & 25 & & & & & & \\
\hline ВH3 & $\mathrm{HL}$ & 33.7 & 22 & $2047 \pm 15$ & $7.61 \pm 0.03$ & $1965^{*}$ & 76 & 0.69 & 25 & & & & & & \\
\hline $\mathrm{BH} 4$ & $\mathrm{HL}$ & 33.7 & 22 & $2632 \pm 12$ & $8.52 \pm 0.02$ & $1979^{*}$ & 468 & 0.70 & 25 & & & & & & \\
\hline
\end{tabular}

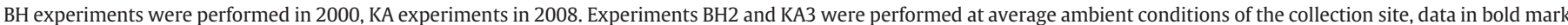

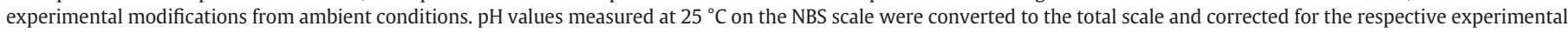

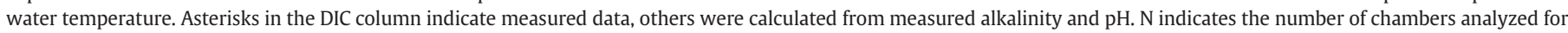
each sample. Two $\mathrm{Ba} / \mathrm{Ca}$ data in brackets deviate by more than $2 \sigma$ from the experimental mean and were not interpreted further. 

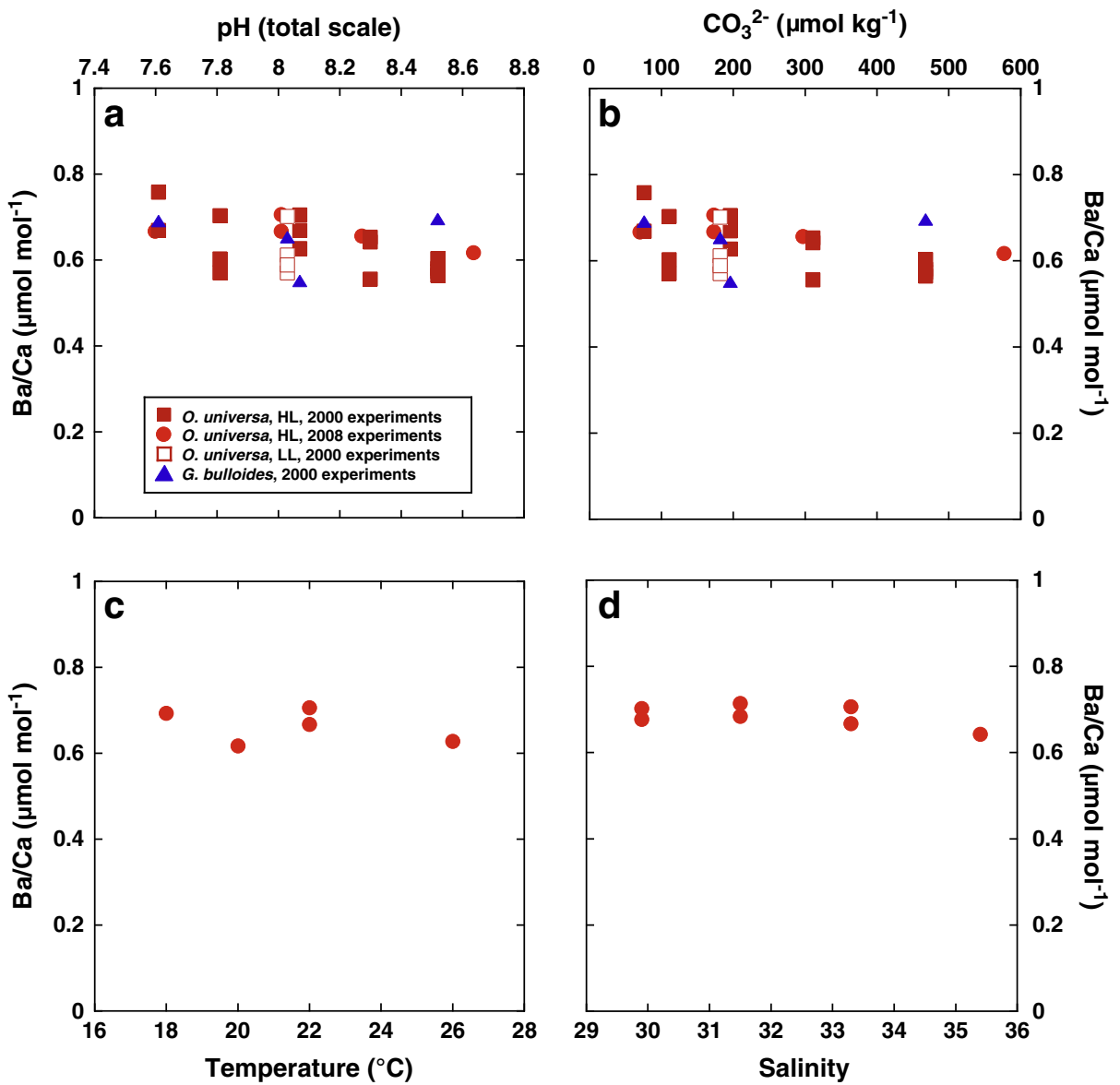

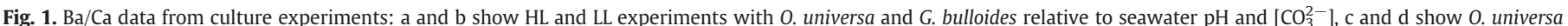
relative to temperature and salinity. The $\mathrm{Ba} / \mathrm{Ca}$ ratio is independent of $\mathrm{pH}$, light level, temperature, salinity or foraminifer species.

foraminifer species and the high light (HL) and low light (LL) experiments are indistinguishable within the individual data variability. Statistical evaluation (student $t$-test, using Matlab) of the $\mathrm{pH}$ relationship measured in 0 . universa shells yields a negative relationship with a slope $(\mathrm{m})$ of $-0.09 \mu \mathrm{mol} / \mathrm{mol}$ per $1 \mathrm{pH}$ unit. Although the relationship is significant (i.e. $\mathrm{m} \neq 0$ ) at a $95 \%$ confidence level, the regression only explains $28 \%$ of the $\mathrm{Ba} / \mathrm{Ca}$ variance $\left(R^{2}=0.28\right)$. For comparison, the average $2 \sigma$ standard deviation of replicates within each experimental

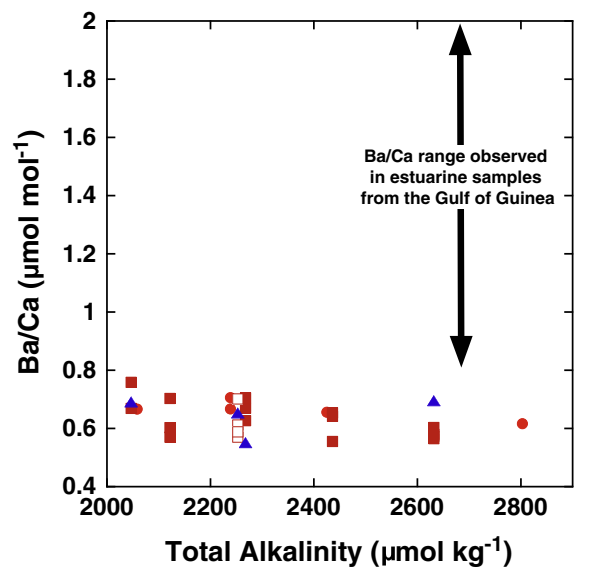

Fig. 2. Same data as in Fig. 1a and b relative to total alkalinity of experimental seawater. Although the individual data variability may be large relative to repeat analysis of consistency standards, the $\mathrm{Ba} / \mathrm{Ca}$ range is small compared to the large variation observed in natural samples such as estuarine foraminiferal $\mathrm{Ba} / \mathrm{Ca}$ ratios from the Gulf of Guinea (Weldeab et al., 2007a). group is $\pm 0.08 \mu \mathrm{mol} / \mathrm{mol}$. With a glacial/interglacial $\mathrm{pH}$-difference of $\sim 0.15$ pH units (Foster, 2008; Hönisch and Hemming, 2005; Sanyal et al., 1995) the glacial/interglacial Ba/Ca change predicted by this observed relationship would not be detectable.

\subsection{Temperature and salinity}

Fig. $1 \mathrm{c}$ and $\mathrm{d}$ show $\mathrm{Ba} / \mathrm{Ca}$ ratios in shells of 0 . universa as a function of culture water temperature and salinity, respectively. No change in the $\mathrm{Ba} / \mathrm{Ca}$ ratio is observed in response to either parameter.

\section{Discussion}

The comparison between symbiont-bearing and symbiont-barren foraminifers, as well as the differing light level experiments with 0 . universa may be seen as an extension of $\mathrm{pH}$ experiments. This is because symbiont photosynthetic activity and the associated $\mathrm{CO}_{2}$ sequestration in planktic foraminifers are known to increase $\mathrm{pH}$ at the site of calcification, and this effect is larger at higher light intensities (Hönisch et al., 2003; Jørgensen et al., 1985; Rink et al., 1998). In contrast, pH in the microenvironment of symbiont-barren foraminifers such as $G$. bulloides is dominated by the $\mathrm{CO}_{2}$-producing processes of respiration and calcification, which lower $\mathrm{pH}$ at the site of calcification (Hönisch et al., 2003). Ba/Ca ratios of 0 . universa grown under high-light and low-light conditions agree at a 95\% confidence level $(0.67 \pm 0.04$ and $0.62 \pm 0.05 \mu \mathrm{mol} / \mathrm{mol}$, respectively), suggesting that variable light intensities and corresponding $\mathrm{pH}$ changes at the site of calcification do not significantly affect Ba incorporation. In general, the data variability $( \pm 0.08 \mu \mathrm{mol} / \mathrm{mol}, 2 \sigma)$ is large compared to the analytical uncertainty of $\sim 0.009 \mu \mathrm{mol} / \mathrm{mol}$, but small compared to the $\mathrm{Ba} / \mathrm{Ca}$ range observed over 


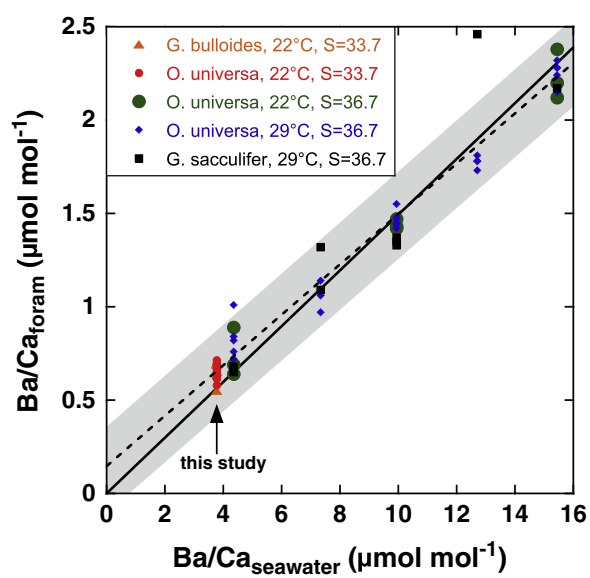

Fig. 3. Ba/Ca ratios in shells of cultured O. universa (Lea and Spero, 1994; this study), G. sacculifer (Lea and Spero, 1994) and G. bulloides (this study) relative to the $\mathrm{Ba} / \mathrm{Ca}$ ratio of experimental seawater. Data by Lea and Spero (1992) are not included in this figure, as their analytical procedure was subsequently improved and earlier data were suspected elevated (Lea and Spero, 1994). Three different foraminifer species were grown at various salinities and temperatures and yet all species (symbiont-bearing and symbiont-barren) and experiments fall on the same partitioning line. The linear regression through this data set is $\mathrm{Ba} / \mathrm{Ca}_{\text {shell }}=0.13+0.14{ }^{*} \mathrm{Ba} / \mathrm{Ca}_{\text {seawater }}$ (dashed line). When forced through the origin, the $\mathrm{Ba} / \mathrm{Ca}$ partitioning for this data set can be described as $\mathrm{Ba} / \mathrm{Ca}_{\text {shell }}=0.15$ $( \pm 0.05) * \mathrm{Ba} / \mathrm{Ca}_{\text {seawater }}$ (solid line) and the linear and forced regression agree on a $95 \%$ confidence level (grey bar).

the past $20 \mathrm{ky}$ in the Arctic Ocean $(\sim 1.3-2.3 \mu \mathrm{mol} / \mathrm{mol}$, Hall and Chan, 2004a), over the past $155 \mathrm{ky}$ in the Gulf of Guinea $(\sim 0.8-2.1 \mu \mathrm{mol} / \mathrm{mol}$, Fig. 2, Weldeab et al., 2007a), and over the past $8 \mathrm{My}$ in the Mediterranean ( 0.5-9.5 $\mu \mathrm{mol} / \mathrm{mol}$, Sprovieri et al., 2008). The sum of our new data and the light experiments performed by Lea and Spero (1992, 1994), suggests that seawater carbonate chemistry does not affect Ba partitioning in spinose planktic foraminifer shells.

The lack of a temperature or salinity effect is consistent with the earlier work of Lea and Spero (1994), who compared Ba/Ca ratios in $O$. universa grown at 22 and $29{ }^{\circ} \mathrm{C}$ and $\mathrm{S}=36.7$ on Lee Stocking Island, Bahamas, and at $22{ }^{\circ} \mathrm{C}$ and $\mathrm{S}=33.7$ on Santa Catalina Island (Lea and Spero, 1992), and found no significant difference between 33.7 and 36.7 salinity or their temperature experiments. It is remarkable how similar the foraminiferal $\mathrm{Ba} / \mathrm{Ca}$ ratio is from these different studies and at different salinities and temperatures (see also Fig. 3). Our new data thus expand the temperature and salinity range over which no change in $\mathrm{Ba} / \mathrm{Ca}$ ratio can be observed to $18-29^{\circ} \mathrm{C}$ and $\mathrm{S}=29.9-36.7$.

In contrast, precipitation experiments have shown that $\mathrm{Ba} / \mathrm{Ca}$ ratios are strongly anti-correlated with temperature in synthetic and scleractinian coral aragonite (Gaetani and Cohen, 2006). Gaetani and Cohen (2006) noted that the temperature correlation is not an equilibrium process and attributed their observation to surface entrapment of Ba during aragonite growth and coralline vital effects (active Ba discrimination into the calcifying fluid and temperature and/ or light dependent enzymatic ion pumping). $\mathrm{Ba}^{2+}$ has an ion radius much larger than $\mathrm{Ca}^{2+}$ and does not substitute as easily into calcite as into aragonite. $\mathrm{Ba} / \mathrm{Ca}$ ratios in calcitic foraminifer shells are therefore much lower than in aragonitic coral skeletons $(<1 \mu \mathrm{mol} / \mathrm{mol}$ vs. $>4 \mu \mathrm{mol} / \mathrm{mol}$ ) and the lack of a temperature or $\mathrm{pH}$ effect is consistent with expectations based on the aqueous chemistry of dissolved $\mathrm{Ba}$. Approximately $96 \%$ of dissolved Ba in seawater exists as a free hydrated metal ion, and only $4 \%$ of Ba may be complexed by sulfate (Byrne et al., 1988). Temperature and $\mathrm{pH}$ exert only a very small influence on such weakly complexed metal ions (Byrne et al., 1988) and thus do not give rise to significant variations in availability for incorporation into marine carbonates. In addition, our empirical calibrations demonstrate that if there were any change of calcification rate in response to higher $\mathrm{pH}$ and temperature, it did not result in measurable discrimination against $\mathrm{Ba}$ incorporation. Vital effects within and between species do not seem to exist for Ba uptake into spinose planktic foraminifer shells. Barium has no reported biochemical function, and because symbiont-bearing $O$. universa grown at high and low light levels record the same $\mathrm{Ba} / \mathrm{Ca}$ ratio as the symbiont-barren $G$. bulloides, Ba partitioning between seawater and foraminiferal calcite does not appear to be influenced by symbiont photosynthetic activity.

Ba partitioning into the shells can be described by a simple partition coefficient $\mathrm{D}_{\mathrm{Ba}}=\mathrm{Ba} / \mathrm{Ca}_{\text {foram }} / \mathrm{Ba} / \mathrm{Ca}_{\text {seawater }}$. The partition coefficients estimated from our new culture data are $\mathrm{D}_{\mathrm{Ba}}=0.17 \pm 0.04(2 \sigma)$ for G. bulloides and $0.17 \pm 0.02(2 \sigma)$ for O. universa. Globigerinoides sacculifer and O. universa grown by Lea and Spero (1994) yield a $\mathrm{D}_{\mathrm{Ba}}$ of $0.15 \pm 0.02$. The combined partition coefficients of core-top fossil spinose planktic foraminifers yield $\mathrm{D}_{\mathrm{Ba}}=0.19 \pm 0.05$ (Lea and Boyle, 1991), and Hall and Chan (2004a) observed $\mathrm{D}_{\mathrm{Ba}}=0.22 \pm 0.02$ for coretop $N$. pachyderma sin. Statistical evaluation (student $t$-test) of these data reveals that the $\mathrm{D}_{\mathrm{Ba}}$ values derived from laboratory culture (this study, Lea and Spero, 1994), where the $\mathrm{Ba} / \mathrm{Ca}$ ratio of the culture medium was measured, agree at a $95 \%$ confidence level. The combined laboratory culture $D_{\mathrm{Ba}}$ value also agrees with the coretop $D_{\mathrm{Ba}}$ from Lea and Boyle (1991) at a $96 \%$ confidence level. However, the $\mathrm{D}_{\mathrm{Ba}}$ from Hall and Chan (2004a) does not agree with the laboratory cultures. It should be noted that we have excluded culture data by Lea and Spero (1992) from this evaluation. That study estimated a $\mathrm{D}_{\mathrm{Ba}}$ of $0.16 \pm 0.01$ for cultured 0 . universa (regression forced through zero) but Lea and Spero (1994) later improved their analytical technique and suspected their earlier analyses of foraminiferal $\mathrm{Ba} / \mathrm{Ca}$ ratios may be too high. Following that line of argument, the coretop study by Lea and Boyle (1991) may also be less reliable than samples measured in/after 1994. Moreover, the coretop studies used average surface ocean $\mathrm{Ba} / \mathrm{Ca}_{\text {seawater values for the }}$ respective ocean basins rather than $\mathrm{Ba} / \mathrm{Ca}_{\text {seawater }}$ which was not measured at each core site. In particular for the Arctic Ocean, where the Lena and Mackenzie Rivers discharge high Ba concentrations of 130 and $520 \mathrm{nmol} / \mathrm{l}$, respectively, the average surface value of $65 \mathrm{nmol} /$ 1 used by Hall and Chan (2004a) to estimate $\mathrm{D}_{\mathrm{Ba}}$ for $\mathrm{N}$. pachyderma may not be accurate for the core site. For future studies estimating $\mathrm{Ba}$ / $\mathrm{Ca}_{\text {seawater }}$ from foraminiferal $\mathrm{Ba} / \mathrm{Ca}$, we therefore recommend to use $\mathrm{D}_{\mathrm{Ba}}$ established from culture studies as the most accurate coefficient. We determine this $\mathrm{D}$ value via a regression through our new culture data combined with previously published 0 . universa and G. sacculifer data (Lea and Spero, 1994). We assume that a foraminifer grown in Ba-free water will not incorporate any Ba into its shell, and accordingly have forced the linear regression shown in Fig. 3 through the origin. Seawater $\mathrm{Ba} / \mathrm{Ca}$ ratios can thus be estimated from foraminiferal $\mathrm{Ba} / \mathrm{Ca}$ ratios as

$\mathrm{Ba} / \mathrm{Ca}_{\text {shell }}=0.149( \pm 0.05) * \mathrm{Ba} / \mathrm{Ca}_{\text {seawater }}$

Forcing the regression through the origin has little overall effect, as the linear and forced regression agree on a 95\% confidence level.

Importantly, we remind the reader that Lea and Boyle (1991) found much higher $\mathrm{D}_{\mathrm{Ba}} \approx 1$ for specimens of the non-spinose Globorotaliid family, i.e. Globorotalia truncatulinoides, G. hirsuta and G. menardii. Lea and Boyle (1991) argued that this may be attributed to a different calcification mechanism but their data are too variable to permit estimation of a coherent $D_{\mathrm{Ba}}$ for the Globorotaliids. One parameter that the Globorotaliids have in common is that they all live in the subsurface, at water depths $>70-300 \mathrm{~m}$ (Farmer et al., 2007), except for G. truncatulinoides which has been reported to live as deep as $700 \mathrm{~m}$ (Mulitza et al., 1999; Steph et al., 2009). Although the seawater Ba concentration increases with depth and may explain higher Ba/Ca ratios in deep living $G$. truncatulinoides, the seawater Ba concentration in the upper $300 \mathrm{~m}$ of the water column is similar to the surface layer, and accordingly we need to consider how [Ba] could be increased in the microenvironment of this particular group of foraminifer species. With no biological function reported, it seems unlikely that foraminifers would actively increase [Ba] in their microenvironment, so the only conceivable ways to increase $\mathrm{Ba}$ incorporation include reduced 
discrimination against Ba during calcification or preying on organisms that concentrate $\mathrm{Ba}$. The $\mathrm{Ba} / \mathrm{Sr}$ partition coefficient in the skeletal material of Acantharia, i.e. celestite $\left(\mathrm{SrSO}_{4}\right)$, is very large with an average value of 3.4, and celestite remineralization takes place largely in the subsurface (Bernstein et al., 1998). Given the Globorotaliids' habitat depth in the subsurface, and the concurrence with the zone of celestite remineralization, we suggest that acantharian celestite could be the source of excess Ba if Globorotaliids feed on this abundant group of zooplankton at depth. This hypothesis could be tested in laboratory feeding experiments with $G$. menardii, which is frequently collected in plankton nets off Santa Catalina Island. If correct, the analysis of $\mathrm{Ba} / \mathrm{Ca}$ ratios in fossil specimens of deep-dwelling planktic foraminifers could even be useful to constrain the evolutionary history of Acantharia, which do not preserve in seafloor sediments.

The $\mathrm{D}_{\mathrm{Ba}}$ established here is strictly only applicable to species of the spinose Globigerinidae, including O. universa, G. sacculifer, G. ruber, G. bulloides and G. conglobatus. Neogloboquadrina pachyderma and $N$. dutertrei are phylogenetically more closely related to the Globorotalia species but the $D_{\mathrm{Ba}}$ is similar to that of the spinose Globigerinidae.

\section{Conclusions}

Our new culture experiments confirm that $\mathrm{pH}$, temperature, salinity and light level do not significantly affect the Ba incorporation into shells of the planktic foraminifers $O$. universa and $G$. bulloides. There is no discernable difference in $\mathrm{Ba} / \mathrm{Ca}$ shell compositions of these two foraminifer species when grown in the same water. These observations, in addition to earlier experiments on the Ba incorporation as a function of the seawater $\mathrm{Ba} / \mathrm{Ca}$ ratio, reinforce the notion that paleo-Ba concentrations of seawater can be estimated from spinose planktic foraminifer shells, and the $\mathrm{D}_{\mathrm{Ba}}$ is $0.15 \pm 0.05$. However, our measurements show that the variability of $\mathrm{Ba} / \mathrm{Ca}$ ratios recorded by individual shells is large compared to the analytical reproducibility of consistency standards. Since bioturbation and potential barite contamination of sedimented shells pose additional complications for paleoreconstructions, we emphasize the need to analyze and replicate samples of multiple foraminifer shells.

\section{Acknowledgments}

We gratefully acknowledge the field help by L. Juranek, M. Thomas, H. Iverson, K. James, and S. Doo. Harry Elderfield kindly gave KA and JY access to the Godwin Lab and we thank the National Environment Research Council (UK) for funding the lab. The experiments could not have been successfully completed without the laboratory work of G. Paradis, D. Pak, J. Day and M. Greaves. Comments by editor Richard Jordan, Syee Weldeab and an anonymous reviewer improved this manuscript. This research was supported by DAAD grant D/00 20292 (BH), Nebroc (JB), NSF grants OCE 0751764 (BH, KA), OCE 9907044 (ADR), OCE 9729203, 9903632, and 0550703 (HJS), and ARC grant DP0880010 (SE, ADR). This is LDEO publication \# 7437.

\section{References}

Bernstein, R.E., Byrne, R.H., Schijf, J., 1998. Acantharians: a missing link in the oceanic biogeochemistry of barium. Deep-Sea Res. Part I-Oceanogr. Res. Pap. 491-505.

Bijma, J., Spero, H.J., Lea, D.W., 1999. Reassessing foraminiferal stable isotope geochemistry: Impact of the oceanic carbonate system (experimental results). In: Fischer, G., Wefer, G. (Eds.), Use of Proxies in Paleoceanography: Examples from the South Atlantic. Springer-Verlag, Berlin, Heidelberg, pp. 489-512.

Byrne, R.H., Kump, L.R., Cantrell, K.J., 1988. The influence of temperature and pH on trace-metal speciation in seawater. Marine Chemistry 25, 163-181.

Chan, L.H., Drummond, D., Edmond, J.M., Grant, B., 1977. On the barium data from the Atlantic GEOSECS expedition. Deep-Sea Research 24, 613-649.

Farmer, E.C., Kaplan, A., de Menocal, P.B., Lynch-Stieglitz, J., 2007. Corroborating ecological depth preferences of planktonic foraminifera in the tropical Atlantic with the stable oxygen isotope ratios of core top specimens. Paleoceanography 22 . doi:10.1029/2006pa001361.

Foster, G.L., 2008. Seawater $\mathrm{pH}, \mathrm{pCO}_{2}$ and $\left[\mathrm{CO}_{3}^{2-}\right]$ variations in the Caribbean Sea over the last 130kyr: A boron isotope and B/Ca study of planktic foraminifera. Earth and Planetary Science Letters 271, 254-266.

Gaetani, G.A., Cohen, A.L., 2006. Element partitioning during precipitation of aragonite from seawater: a framework for understanding paleoproxies. Geochimica et Cosmochimica Acta 70, 4617-4634

Hall, J.M., Chan, L.H., 2004a. Ba/Ca in Neogloboquadrina pachyderma as an indicator of deglacial meltwater discharge into the western Arctic Ocean. Paleoceanography 19, 9. doi:10.1029/2003pa000910.

Hall, J.M., Chan, L.H., 2004b. Ba/Ca in benthic foraminifera: thermocline and middepth circulation in the North Atlantic during the last glaciation. Paleoceanography 19, 13. doi:10.1029/2004pa001028.

Hathorne, E.C., James, R.H., Lampitt, R.S., 2009. Environmental versus biomineralization controls on the intratest variation in the trace element composition of the planktonic foraminifera G. inflata and G. scitula. Paleoceanography 24. doi:10.1029/ 2009pa001742.

Hönisch, B., Hemming, N.G., 2005. Surface ocean pH response to variations in $\mathrm{pCO}_{2}$ through two full glacial cycles. Earth and Planetary Science Letters 236, 305-314.

Hönisch, B., Bijma, J., Russell, A.D., Spero, H.J., Palmer, M.R., Zeebe, R.E., Eisenhauer, A., 2003. The influence of symbiont photosynthesis on the boron isotopic composition of foraminifera shells. Marine Micropaleontology 49, 87-96.

Jørgensen, B.B., Erez, J., Revsbech, N.P., Cohen, Y., 1985. Symbiotic photosynthesis in a planktonic foraminiferan, Globigerinoides sacculifer (Brady), studied with microelectrodes. Limnology and Oceanography 30, 1253-1267.

Kisakürek, B., Eisenhauer, A., Böhm, F., Garbe-Schönberg, D., Erez, J., 2008. Controls on shell $\mathrm{Mg} / \mathrm{Ca}$ and $\mathrm{Sr} / \mathrm{Ca}$ in cultured planktonic foraminiferan, Globigerinoides ruber (white). Earth and Planetary Science Letters 273, 260-269.

Lea, D.W., 1993. Constraints on the alkalinity and circulation of glacial circumpolar deep water from benthic foraminiferal barium. Global Biogeochemical Cycles 7, 695-710.

Lea, D.W., Boyle, E.A., 1989. Barium content of benthic foraminifera controlled by bottom-water composition. Nature 338, 751-753.

Lea, D.W., Boyle, E.A., 1990a. A 210,000-year record of barium variability in the deep northwest Atlantic Ocean. Nature 347, 269-272.

Lea, D.W., Boyle, E.A., 1990b. Foraminiferal reconstruction of barium distributions in water masses of the glacial oceans. Paleoceanography 5, 719-742.

Lea, D.W., Boyle, E.A., 1991. Barium in planktonic foraminifera. Geochimica et Cosmochimica Acta 55, 3321-3331

Lea, D.W., Martin, P.A., 1996. A rapid mass spectrometric method for the simultaneous analysis of barium, cadmium, and strontium in foraminifera shells. Geochimica et Cosmochimica Acta 60, 3143-3149.

Lea, D.W., Spero, H.J., 1992. Experimental determination of barium uptake in shells of the planktonic foraminifera Orbulina universa at $22^{\circ} \mathrm{C}$. Geochimica et Cosmochimica Acta 56, 2673-2680.

Lea, D.W., Spero, H.J., 1994. Assessing the reliability of paleochemical tracers: barium uptake in the shells of planktonic foraminifera. Paleoceanography 9, 445-452.

Lea, D.W., Mashiotta, T.A., Spero, H.J., 1999. Controls on magnesium and strontium uptake in planktonic foraminifera determined by live culturing. Geochimica et Cosmochimica Acta 63, 2369-2379.

Mashiotta, T.A., Lea, D.W., Spero, H.J., 1997. Experimental determination of Cd uptake in shells of the planktonic foraminifera Orbulina universa and Globigerina bulloides: implications for surface water paleoreconstructions. Geochimica et Cosmochimica Acta 61, 4053-4065.

Mulitza, S., Arz, H., Kemle-von Mücke, S., Moos, C., Niebler, H.-S., Pätzold, J., Segl, M., 1999. The South Atlantic carbon isotope record of planktonic foraminifera. In: Fischer, G., Wefer, G. (Eds.), Use of proxies in paleoceanography: Examples from the South Atlantic. Springer Verlag, Berlin Heidelberg, pp. 427-445.

Rink, S., Kühl, M., Bijma, J., Spero, H.J., 1998. Microsensor studies of photosynthesis and respiration in the symbiotic foraminifer Orbulina universa. Mar. Biol. 131, 583-595.

Russell, A.D., Hönisch, B., Spero, H.J., Lea, D.W., 2004. Effects of changes in seawater carbonate ion concentration and temperature on shell $\mathrm{U} / \mathrm{Ca}, \mathrm{Mg} / \mathrm{Ca}$, and $\mathrm{Sr} / \mathrm{Ca}$ of planktonic foraminifera. Geochimica et Cosmochimica Acta 68, 4347-4361.

Sanyal, A., Hemming, N.G., Hanson, G.N., Broecker, W.S., 1995. Evidence for a higher pH in the glacial ocean from boron isotopes in foraminifera. Nature 373, 234-236.

Spero, H.J., Bijma, J., Lea, D.W., Bemis, B.E., 1997. Effect of seawater carbonate concentration on foraminiferal carbon and oxygen isotopes. Nature 390, 497-500.

Sprovieri, M., d'Alcala, M.R., Manta, D.S., Bellanca, A., Neri, R., Lirer, F., Taberner, C., Pueyo, J.J., Sammartino, S., 2008. Ba/Ca evolution in water masses of the Mediterranean late Neogene. Paleoceanography 23, 17. doi:10.1029/2007pa001469.

Steph, S., Regenberg, M., Tiedemann, R., Mulitza, S., Nürnberg D. 2009. Stable isotopes of planktonic foraminifera from tropical Atlantic/Caribbean core-tops: Implications for reconstructing upper ocean stratification. Marine Micropaleontology 71, 1-19.

Weldeab, S., Lea, D.W., Schneider, R.R., Andersen, N., 2007a. 155,000 years of west African monsoon and ocean thermal evolution. Science 316, 1303-1307.

Weldeab, S., Lea, D.W., Schneider, R.R., Andersen, N., 2007b. Centennial scale climate instabilities in a wet early Holocene West African monsoon. Geophysical Research Letters 34, L24702.

Yu, J., Day, J., Greaves, M., Elderfield, H., 2005. Determination of multi-element/calcium ratios in foraminiferal calcite by quadropole ICP-MS and its application for paleoceanographic studies. Geochemistry Geophysics Geosystems 6. doi:10.1029/2005GC000964.

Zeebe, R.E., 2001. Seawater $\mathrm{pH}$ and isotopic paleotemperatures of Cretaceous oceans. Palaeo 170, 49-57. 